\begin{abstract}
Iranica
Abstracta Iranica Revue bibliographique pour le domaine irano-aryen

Volume 34-35-36 | 2017

Comptes rendus des publications de 2011-2013
\end{abstract}

\title{
Silvia Schroer, Patrick Wyssmann. Eine Göttin auf dem Löwen aus Hirbet Qēyafa
}

\section{Astrid Nunn}

\section{(2) OpenEdition}

\section{Journals}

\section{Édition électronique}

URL : http://journals.openedition.org/abstractairanica/41636

DOI : 10.4000/abstractairanica.41636

ISSN : 1961-960X

Éditeur :

CNRS (UMR 7528 Mondes iraniens et indiens), Éditions de l'IFRI

Référence électronique

Astrid Nunn, «Silvia Schroer, Patrick Wyssmann. Eine Göttin auf dem Löwen aus Hirbet Qēyafa », Abstracta Iranica [En ligne], Volume 34-35-36 | 2017, document 63, mis en ligne le 15 juillet 2016, consulté le 26 septembre 2020. URL : http://journals.openedition.org/abstractairanica/41636 ; DOI : https://doi.org/10.4000/abstractairanica.41636

Ce document a été généré automatiquement le 26 septembre 2020.

Tous droits réservés 


\title{
Silvia Schroer, Patrick Wyssmann. Eine Göttin auf dem Löwen aus Hirbet Qēyafa
}

\author{
Astrid Nunn
}

\section{RÉFÉRENCE}

Silvia Schroer, Patrick Wyssmann. « Eine Göttin auf dem Löwen aus Hirbet Qēyafa ». ZDPV, 128/2, 2012, p. 158-169.

1 Un scaraboïde en verre a été trouvé lors des fouilles à Huirbet Qēyafa en 2009. On y voit un personnage, dont la tête est abîmée, debout sur un lion et tenant une lance dans la main droite. Devant lui se trouve un thymiaterion. Ce type iconographique est moins connu en Israël qu'en Mésopotamie où il représente la déesse Ishtar. Les AA. ont néanmoins reconstitué la tête en lion et font ainsi du personnage la déesse Sakhmet. Nous n'en voyons pas la raison d'autant moins qu'un scarabée très semblable d'Ibiza montre une «Ichtar» sur un lion. En revanche, la datation achéménide, est certainement correcte.

\section{AUTEURS}

ASTRID NUNN

Université de Munich 